\title{
FTY720, a sphingosine 1-phosphate receptor modulator, inhibits CD1d-restricted NKT cells by suppressing cytokine production but not migration
}

\author{
Su Jin Hwang ${ }^{1,2, *, \dagger}$, Ji Hyung Kim ${ }^{1,2, *}$, Hye Young Kim ${ }^{1, \ddagger}$, Sanghee $\mathrm{Kim}^{3}$ and Doo Hyun Chung ${ }^{1,2}$
}

FTY720, a sphingosine 1-phosphate (S1P) receptor modulator, suppresses immune responses by inhibiting T-cell migration into target tissues; however, it does not alter T-cell functions. In this study, we investigated the biological effects of FTY720 on NKT cells. Unlike T cells, FTY720 suppressed the production of IL-4, IFN- $\gamma$, IL-10, and IL-13 by NKT cells through the S1P1 receptor $\left(\mathrm{S}_{1} \mathrm{P}_{1}\right)$. Moreover, FTY720 also inhibited the expression of T-bet and GATA-3 of NKT cells in the presence of TCR engagement. However, it did not inhibit NKT cell migration in vitro or in vivo. In a K/BxN serum transfer arthritis model, FTY720 suppressed arthritis in B6, but not in $\mathrm{CD}_{1} \mathrm{~d}^{-/-}$mice. Moreover, the adoptive transfer of control NKT cells restored arthritis in CD1d ${ }^{-1-}$ mice, whereas FTY720-pretreated NKT cells did not. The number of NKT cells in the joints of B6 mice given FTY720 was similar to that in the joints of untreated B6 mice, whereas the production of IL-4 and IFN- $\gamma$ was reduced in the FTY720-treated B6 mice. Taken together, these data show that FTY720 suppresses cytokine production in NKT cells through $\mathrm{S1P}_{1}$, but not NKT cell migration. Thus, FTY720 may be useful in the treatment of NKT cell-promoted immune diseases.

Laboratory Investigation (2010) 90, 9-19; doi:10.1038/labinvest.2009.109; published online 12 October 2009

KEYWORDS: NKT cells; FTY720; inhibition; S1P1 receptor; cytokine; migration

NKT cells are a distinct class of $\mathrm{T}$ cells characterized by the coexpression of TCR and NK cell receptor. ${ }^{1}$ Murine NKT cells express a semi-invariant V $\alpha 14-\mathrm{J} \alpha 18$ TCR, whereas human NKT cells express an invariant V $\alpha 24-\mathrm{J} \alpha 15 \mathrm{TCR},{ }^{2}$ which recognizes glycolipid antigens complexed with $\mathrm{CD} 1 \mathrm{~d} .{ }^{3} \mathrm{On}$ activation, NKT cells rapidly secret large amounts of IL-4 and IFN- $\gamma$, which contribute to the regulation of innate and adaptive immune responses by NKT cells. ${ }^{1,4}$ Therefore, NKT cells regulate various immune responses related to autoimmune diseases, hypersensitivity pneumonia, pulmonary fibrosis, oral tolerance, transplantation rejection, and graftversus-host disease. ${ }^{1,4-10}$ In addition, they enhance the immune response to tumors, microorganisms, and inflammation. ${ }^{4,11,12}$ The results of a recent phase I clinical trial using V $\alpha 24$ NKT cells activated by $\alpha$-galactosyl ceramide $(\alpha$-GalCer) in patients with advanced and recurrent nonsmall-cell cancer ${ }^{13}$ suggested that activating reagents for NKT cells may be good candidates for regulating immune disease. However, NKT cells also promote, rather than suppress, immune diseases. ${ }^{4,14,15}$ Therefore, it has been suggested that the suppressive reagents for NKT cell function might be useful in regulating some of the immune diseases promoted by NKT cells.

Sphingosine 1-phosphate (S1P), a biologically active sphingolipid, is produced by hematopoietic cells, such as platelets and red blood cells. ${ }^{16,17}$ S1P mediates various cellular responses, including proliferation, cytoskeletal organization, adhesion, and migration, which are mediated through five G-protein-coupled S1P receptor subtypes. ${ }^{18}$ The concentration of S1P is relatively high in blood but lower in the lymphoid organs, resulting in S1P concentration gradient. This gradient serves as a potent signal for the egression of lymphocytes from secondary lymphoid organs. ${ }^{19}$ Therefore, in the immune system, S1P regulates the trafficking of $\mathrm{T}$ and

\footnotetext{
${ }^{1}$ Department of Pathology, Seoul National University College of Medicine, Seoul, Korea; ${ }^{2}$ Laboratory of Immune Regulation in Department of Biomedical Sciences, Seoul National University College of Medicine, Seoul, Korea and ${ }^{3}$ College of Pharmacy, Seoul National University, Seoul, Korea

Correspondence: Professor DH Chung, MD, PhD, Department of Pathology, Seoul National University College of Medicine, Biomedical Science Building, Room 306, 101, Daehangno, Jongno-gu, Seoul 110-744, Korea.

E-mail: doohyun@snu.ac.kr

*These authors contributed equally to this work.

${ }^{\dagger}$ Current address: Section on Cellular and Developmental Biology, NICHD, National Institute of Health, Bethesda, MD, USA

${ }^{\ddagger}$ Current address: Division of Immunology, Children's Hospital Boston, Harvard Medical School, Boston, MA, USA.
}

Received 31 May 2009; revised 9 July 2009; accepted 6 August 2009 
B cells between the lymphatic and blood systems by inducing their egression from lymphoid organs. ${ }^{20}$ Moreover, S1P regulates cytokine production in $\mathrm{T}$ and dendritic cells. ${ }^{21,22}$ FTY720, a potent immune suppressant, is phosphorylated to FTY720p by sphingosine kinase 2 in vivo, and phosphorylated FTY720 (FTY720p) functions as a high-affinity agonist for S1P receptors. ${ }^{23}$ FTY720 induces lymphopenia and decreases T-cell infiltration into target organs by sequestering circulating lymphocytes in secondary lymphoid organs. ${ }^{24,25}$ Therefore, FTY720 acts as an immune suppressant in vivo. However, FTY720 does not impair T-cell functions, such as activation or cytokine production. ${ }^{18,25}$ A recent study has shown that $\mathrm{S}_{1} \mathrm{P}_{1,2}$ and $\mathrm{S}_{1} \mathrm{P}_{4}$ mRNA were significantly detected in invariant NKT cells, whereas the transcription level of $\mathrm{S}_{1} \mathrm{P}_{3}$ was relatively low, ${ }^{26}$ suggesting that NKT cells express various S1P receptors. Moreover, it was reported that the $\mathrm{S} 1 \mathrm{P} 1$ receptor $\left(\mathrm{S}_{1} \mathrm{P}_{1}\right)$ is essential for the migration of NKT cells from the thymus into the peripheral lymphoid tissues. ${ }^{26}$ These findings suggest that FTY720 has a critical role in the modulation of immune responses by NKT cells. However, the functional roles of FTY720 in NKT cells are largely unknown. Therefore, we investigated the pharmacological effects of FTY720 on NKT cells and characterized its mechanism of action. We found that, unlike conventional $\mathrm{T}$ cells, FTY720 inhibits NKT cell function by inhibiting cytokine production, but it has no effect on migration.

\section{MATERIALS AND METHODS \\ Mice}

C57BL/6 (B6) mice were purchased from Orient Company Ltd (Seoul, Korea) at 8-10 weeks of age. KRN TCR transgenic mice and NOD mice, obtained from Drs D. Mathis and C. Benoist (Harvard Medical School, Boston, MA, USA) and from the Institut de Genetique et de Biologie Moleculaire et Cellulare (Strasbourg, France), were maintained in a B6 background $(\mathrm{K} / \mathrm{B})$. Arthritic mice $(\mathrm{K} / \mathrm{BxN})$ were obtained by crossing $\mathrm{K} / \mathrm{B}$ with $\mathrm{NOD}(\mathrm{N})$ mice. $\mathrm{CD} 1 \mathrm{~d}^{-/-}$mice were obtained from the NIAID-Taconic facility of the National Institutes of Health (Dr Hua Gu). All mice were maintained in a specific pathogen-free environment at the Clinical Research Institute of Seoul National University Hospital. All animal experiments were approved by the Institutional Animal Care and Use Committee of the AAALAC-accredited Clinical Research Institute at the Seoul National University Hospital.

\section{Reagents and Antibodies}

FTY720 was prepared as a hydrochloride salt according to a custom procedure. ${ }^{27}$ FTY720p was synthesized in racemic form from FTY720 using a modified version of a previously described method. ${ }^{28}$ D-erythro-sphingosine-1-phosphate (S1P) was purchased from Biomol International, LP (Plymouth Meeting, PA, USA) and dissolved in DMSO. Pertussis toxin (PTX) was purchased from Sigma-Aldrich (P2980, St Louis, MO, USA).

\section{In Vivo Administration of $\alpha$-GalCer}

C57BL/6 and $\mathrm{CD} 1 \mathrm{~d}^{-1-}$ mice were intraperitoneally (i.p.) injected with $1 \mu \mathrm{g} \alpha$-GalCer (Alexis, San Diego, CA, USA, or synthesized according to a previously reported protocol ${ }^{29}$ ) dissolved in PBS $(300 \mu \mathrm{l})$.

\section{Cell Preparation and Sorting}

For the preparation of hepatic mononuclear cells, the livers were homogenized and resuspended in loading buffer (PBS plus $10 \%$ FBS and $1 \mathrm{mM}$ EDTA) and overlaid onto lympholyte-M (Cedarlane, ON, Canada). After centrifugation for 20 min at $900 \times g$ at $15^{\circ} \mathrm{C}$, hepatic mononuclear cells were isolated from the interface. The thymus and lymph nodes were homogenized to create single-cell suspension, whereas red blood cells from the spleens and bone marrow (BM) were removed using the lysis solution (PUREGENE; Gentra Systems). For sorting of the NKT cells, hepatic mononuclear cells were stained with PE-conjugated anti-NK1.1 (BD Bioscience, San Diego, CA, USA) and CyChrome-conjugated anti-TCR- $\beta$ (BD Bioscience). The stained cells were then sorted by FACStarPlus using the CellQuest software. The purity of the sorted cells was $>98 \%$.

\section{Transwell Migration Assay}

Liver mononuclear cells, and sorted T or NKT cells were preincubated with FTY720p $(1 \mu \mathrm{g})$, or PTX $(50 \mathrm{ng})$, and then washed with PBS. Liver mononuclear cells $\left(1 \times 10^{5}\right.$ cells per chamber), sorted NKT cells $\left(1 \times 10^{4}\right.$ cells per chamber), or T cells $\left(5 \times 10^{4}\right.$ cells per chamber) were placed in the upper chamber of a Costar plate $(5.0-\mu \mathrm{m}$-pore size membrane; Corning Incorporated Costar Transwell), whereas 600-800 $\mu \mathrm{l}$ of media containing $1 \mu \mathrm{g} / \mathrm{ml}$ of S1P, SEW2871 (Calbiochem, UK), or CCL19 (Milteny Biotec GambH) was placed in the bottom chamber. After 24 or $12 \mathrm{~h}$ of incubation, the cells in the upper and bottom chambers were stained with PE-conjugated anti-NK1.1 and CyChrome-conjugated anti-TCR $\beta$ mAbs or without staining with these antibodies, and counted. The migration index was calculated as the percentage of cells that migrated into the bottom chambers among total cells incubated in the upper chambers.

\section{ELISA}

Sorted NKT cells $\left(2 \times 10^{5}\right.$ cells per well $)$ were incubated with anti-CD3 $\mathrm{mAb}(0.5 \mu \mathrm{g} / \mathrm{ml})$ and/or FTY720p or S1P for $48 \mathrm{~h}$ in a 12-well plate. In addition, hepatic mononuclear cells were stimulated with $\alpha$-GalCer, or $\alpha$-GalCer + FTY720p, or S1P for $24 \mathrm{~h}$. The culture supernatants were subjected to ELISA according to the manufacturer's instructions (BD Bioscience).

\section{Intracellular Staining of T-bet and GATA-3}

For intracellular staining of T-bet and GATA-3, hepatic mononuclear cells were incubated with GolgiPlug for $24 \mathrm{~h}$, and then stained with anti-NK1.1 and TCR- $\beta$ mAb. After surface staining, the cells were resuspended in Fixation/Permeabilization 
solution (BD Bioscience) and stained with anti-T-bet or GATA-3 mAbs according to the manufacturer's protocol.

\section{Serum Transfer and Arthritis Scoring}

$\mathrm{K} / \mathrm{BxN}$ mice with arthritis were bled and the sera were pooled. Recipient mice were then injected i.p. with $150 \mu \mathrm{l}$ of the pooled $\mathrm{K} / \mathrm{BxN}$ sera on days 0 and 2. Ankle thickness was measured using calipers (Manostat, Switzerland). Joint swelling was monitored and scored as follows: 0 , no joint swelling; 1 , swelling of one finger joint; 2 , mild swelling of the wrist or ankle; and 3, severe swelling of the wrist or ankle. To test the biological effects of FTY720 or S1P on serum transfer arthritis, $20 \mu \mathrm{g}$ of FTY720 or S1P was injected i.p. into B6 or $\mathrm{CD} \mathrm{d}^{-/-}$mice 1 day before the first injection of $\mathrm{K} / \mathrm{BxN}$ serum.

\section{Adoptive Transfer Experiment}

Sorted NKT cells were incubated with FTY720p ( $1 \mu \mathrm{g}$ in $1 \mathrm{ml})$ or none for $15 \mathrm{~min}$, and then washed twice with PBS. These cells (in $500 \mu \mathrm{l}$ PBS) were injected intravenously into CD1d ${ }^{-/-}$ mice 2 days before the first injection of $\mathrm{K} / \mathrm{BxN}$ serum.

\section{Real-Time-PCR Analysis}

For real-time PCR, total RNA was isolated from the joint tissue, spleen, or liver mononuclear cells using an RNeasy kit (Qiagen, Valencia, CA, USA) according to the manufacturer's instructions. The RNA was then reverse transcribed using MMLV-RT Taq polymerase (Koschem, Seoul, Korea) before PCR. A total of $1 \mu \mathrm{g}$ cDNA was amplified using TaqMan Universal Master Mix (Perkin-Elmer Biosystems, Waltham, MA, USA), a gene-specific TaqMan probe, forward and reverse primers, and water. Gene-specific amplication was measured using an Applied Biosystems 7500 Sequence Detection System (Perkin-Elmer Biosystems); the results for each cytokine were normalized $v s$ GAPDH expression. The following primers and probes were synthesized by Applied Biosystems or Biosource: GAPDH (TagMan pre-developed Assay Reagent: 4352339E); IFN- $\gamma$ (TaqMan pre-developed Assay Reagent: 4339850F); T-bet (Mm00450960_m1), GATA-3 (Mm00484683_m1), TGF- $\beta_{1}$, GCAACATGTGGAACTCTACC AGAA (forward), GACGTCAAAAGACAGCCACTCA (reverse), and FAM-ACCTTGGTAACCGGCTGCTGACCC-TAMRA; IL-4 (Biosource predeveloped Assay Reagent: Primer Set GMC0044); V $\alpha 14-J \alpha 18$ TCR: GTGTGGTGGGCGATAGAG GT (forward) ACAACCAGCTGAGTCCCAGC (reverse), and FAM-CAGCCTTAGGGAGGCTGCATTTTGG-TAMRA.

\section{Statistical Analysis}

Statistical significance was analyzed using Prism3.0 (GraphPad Software). Student's $t$-tests were used to determine the $P$-value when comparing two groups. $P$-values $<0.05$ were considered significant. One-way ANOVA test was performed and then the post test was conducted if overall $P<0.05$ for the migration index. The results are expressed as a mean + s.e.m.

\section{RESULTS \\ FTY720 Suppresses the Migration of T Cells but not of NKT Cells}

FTY720 is an immune suppressant that inhibits the migration of conventional $\mathrm{T}$ cells to target organs. Therefore, we compared the pharmacological effects of FTY720 on the S1Pinduced migration of conventional T cells and NKT cells. To address this issue, we measured the number of total cells, $\mathrm{T}$, $\mathrm{NK}$, and NKT cells in the BM, spleen, thymus, liver, and lymph nodes from the FTY720-treated B6 mice and control mice. Cell numbers in the thymus and lymph nodes from the FTY720-treated B6 mice were higher than those from the control B6 mice, whereas cell numbers in the BM, spleen, and liver from the control mice were similar to those from the FTY720-treated B6 mice (Figure 1a). The number of T cells in the thymus, lymph nodes, and spleen of B6 mice injected with FTY720 was significantly higher than that in control B6 mice, whereas FTY720 injection reduced the number of T cells in the livers of B6 mice. However, NKT and NK cell numbers in the thymus, lymph nodes, spleen, liver, and BM were similar to each other (Figure 1b-f). These findings suggest that FTY720 inhibits T-cell migration from the thymus, lymph nodes, and spleen into the blood, but it does not suppress NKT and NK cell migration. To confirm this suggestion in vitro, we investigated the S1P-induced migration of T and NKT cells using a transwell system with a semipermeable membrane. First, to investigate whether S1P induces the migration of $\mathrm{T}$ and NKT cells, and to determine which S1P receptors are involved in the induction of $\mathrm{T}$ and NKT cell migration, liver mononuclear cells from B6 mice were incubated in the upper chamber of a transwell system with or without pre-incubation with FTY720p or PTX. Here, PTX uncouples $G_{i}$ and $G_{o}$ proteins from S1P receptors by catalyzing the ADP-ribosylation of $\alpha$-subunits, resulting in blocking signal transduction. ${ }^{30}{\mathrm{~S} 1 \mathrm{P}_{1}}_{1}$ signals exclusively through PTX-sensitive $G_{i}$ and $G_{0}$ proteins, whereas $S_{1} P_{2}$, $\mathrm{S} \mathrm{P}_{3}, \mathrm{~S}_{1} \mathrm{P}_{4}$, and $\mathrm{S}_{1} \mathrm{P}_{5}$ couple to the PTX-sensitive as well as PTX-insensitive $G_{12}, G_{13}$, or $G_{q}$ proteins. ${ }^{31-33}$ Therefore, all effects of $\mathrm{S}_{1} \mathrm{P}_{1}$ are PTX sensitive. Moreover, SEW2871 selectively binds and activates $\mathrm{S}_{1} \mathrm{P}_{1}$ through a combination of hydrophobic and ion-dipole interaction. ${ }^{34}$ On S1P or SEW2871 stimulation, $\mathrm{T}$ and NKT cells migrated into the bottom chamber. PTX inhibited the S1P-induced migration of $\mathrm{T}$ and NKT cells. These results suggest that S1P induces $\mathrm{T}$ - and NKT-cell migration by engaging $\mathrm{S}_{1} \mathrm{P}_{1}$ rather than others (Figure 2a). Moreover, FTY720p inhibited S1P or SEW2871-induced migration of T cells but not of NKT cells (Figure 2a-d). Therefore, to further examine whether FTY720p inhibits the S1P or SEW2871-induced migration of NKT cells in vitro, sorted T or NKT cells were incubated with or without FTY720p in the upper chamber of a transwell system and induced to migrate into the bottom chamber by an S1P or SEW2871 gradient. FTY720 is rapidly phosphorylated in vivo, and, therefore, FTY720p rather than FTY720 acts as a modulator of S1P receptor. ${ }^{35}$ Thus, we used 
a

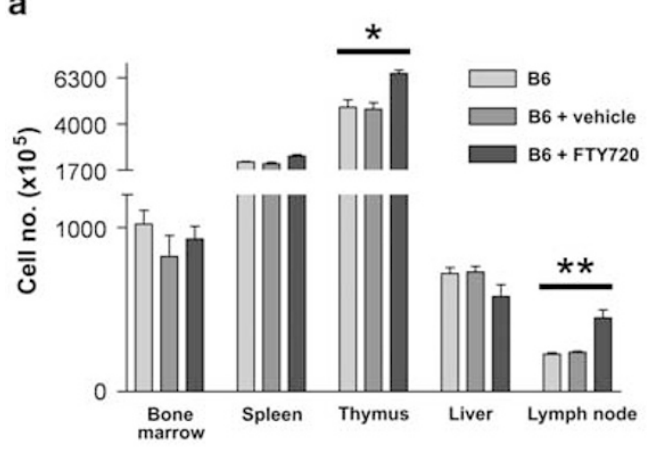

C

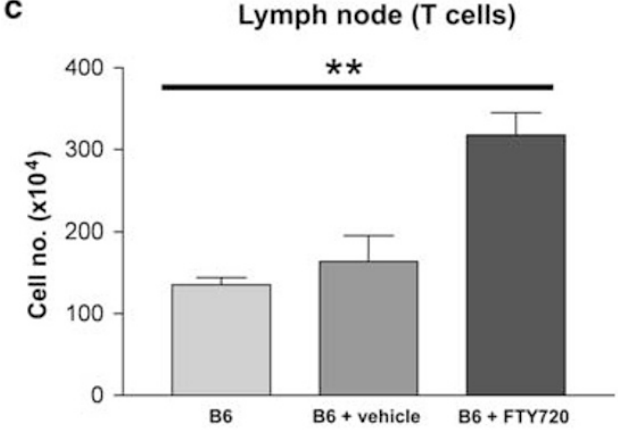

e

Liver

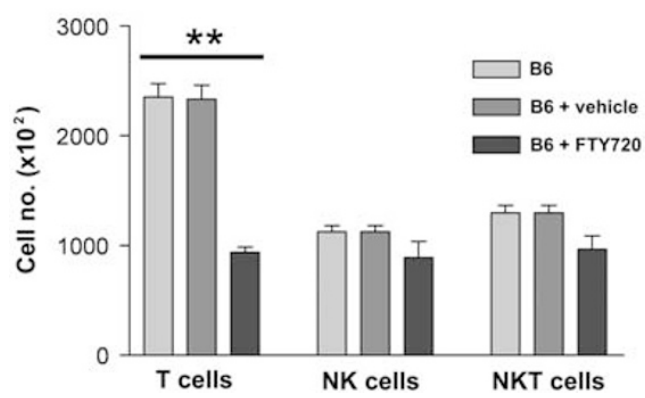

b

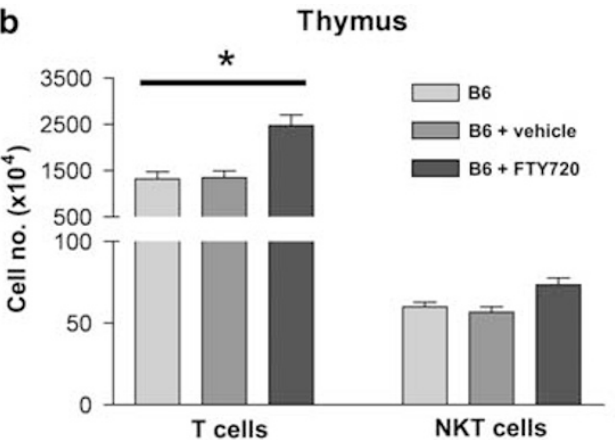

d

Spleen

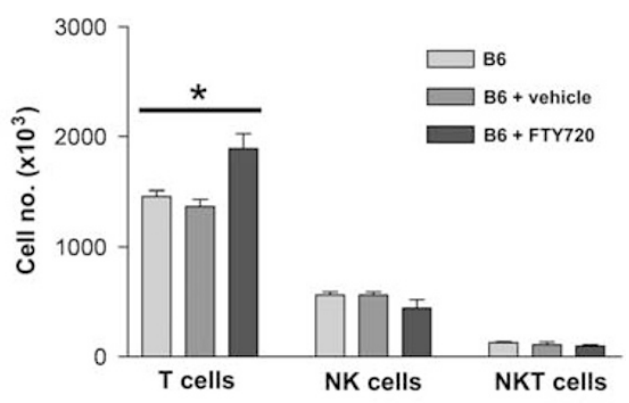

f

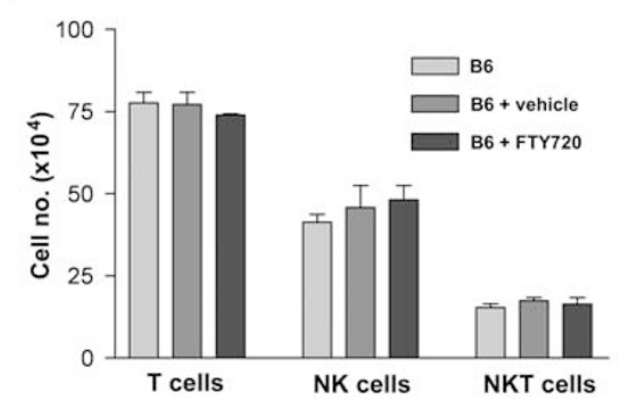

Figure 1 B6 mice injected with FTY720 show sequestration of T cells in the thymus and lymph nodes but not of NKT cells in the primary and secondary lymphoid organs. (a) The bone marrow, spleen, thymus, liver, and lymph nodes were collected from control B6 and B6 mice intraperitoneally injected with FTY720 (20 $\mu \mathrm{g}$ per mouse) or vehicle ( $20 \mu \mathrm{g}$ per mouse) $24 \mathrm{~h}$ before the killing, and the cell numbers in the organs were counted. (b-f) The cells obtained from the organs were stained with anti-NK1.1 and TCR- $\beta$ mAb to count the numbers of T, NK, and NKT cells. The results shown are representative of four independent experiments ( $n=3$ in each group; ${ }^{*} P<0.05$ and ${ }^{*} P<0.01$, B6 mice or B6 mice + vehicle vs B6 mice + FTY720).

FTY720p in our in vitro experiments, whereas FTY720 was administered in our in vivo experiments. FTY720p inhibited S1P or SEW2871-induced T-cell migration into the bottom chamber, whereas it had little effect on S1P or SEW2871induced NKT cell migration (Figure 2a-d). These data indicate that FTY720p suppresses the S1P or SEW2871-induced migration of $\mathrm{T}$ cells but not of NKT cells.

\section{FTY720 and S1P Suppress Cytokine Production by NKT Cells Through S1P}

On activation, NKT cells rapidly produce large amounts of IL-4, IL-10, IL-13, and IFN- $\gamma{ }^{36}$ which contribute to the regulation of various immune responses in vivo. Therefore, to investigate the functional roles of FTY720 and S1P in the production of cytokines by NKT cells, we measured the amounts of cytokines, (eg, IL-4, IL-10, IL-13, and IFN- $\gamma$ ) secreted from NKT cells after S1P receptor and/or CD3 engagement. The titration assays showed that $1 \mu \mathrm{g} / \mathrm{ml}$ was the optimal concentration of S1P or FTY720 to suppress cytokine production of NKT cells in vitro (data not shown). FTY720p and S1P reduced the production of IL- 4 , IFN- $\gamma$, IL-10, and IL-13 by NKT cells in the presence of TCR engagement (Figure 3a). S1P suppressed the production of IL-4 and IFN- $\gamma$ of $\mathrm{T}$ cells but enhanced the production of IL-10 in the presence of TCR engagement, whereas FTY720 did not alter cytokine production of $\mathrm{T}$ cells (Figure $3 \mathrm{a}$ ). To confirm the suppressive effects of S1P and FTY720 on NKT cell cytokine production in vivo, we injected the $\mathrm{B} 6$ and $\mathrm{CD}^{-1-}$ mice 
a

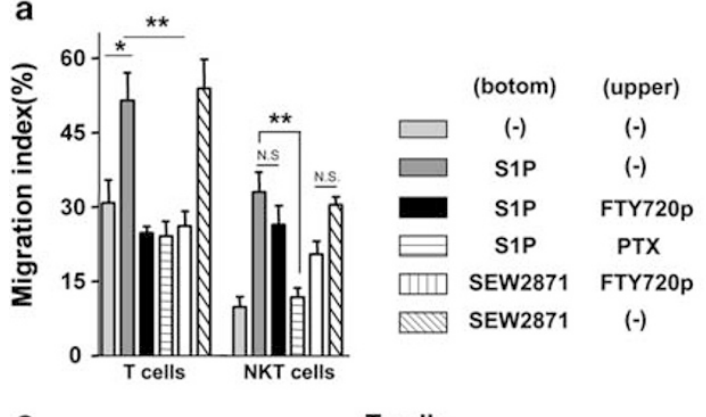

C

T cells
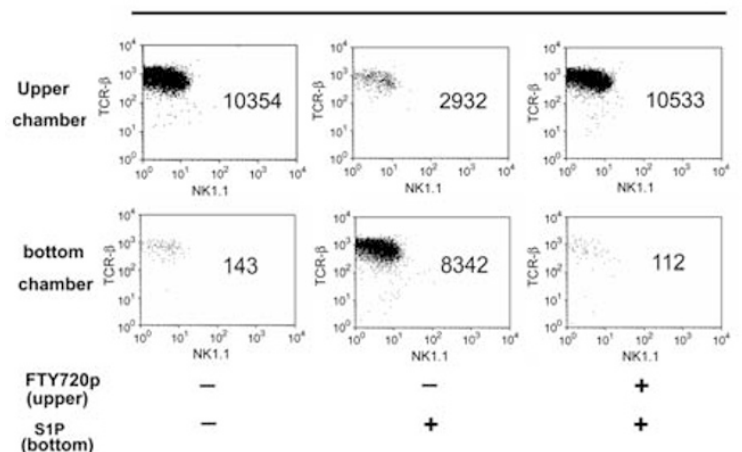

NKT cells
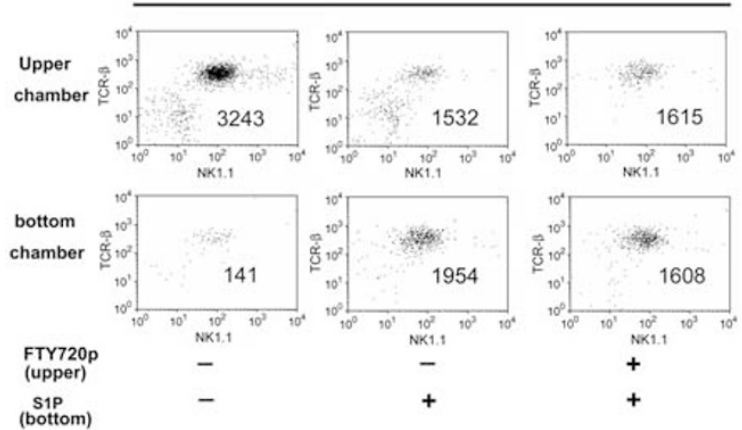
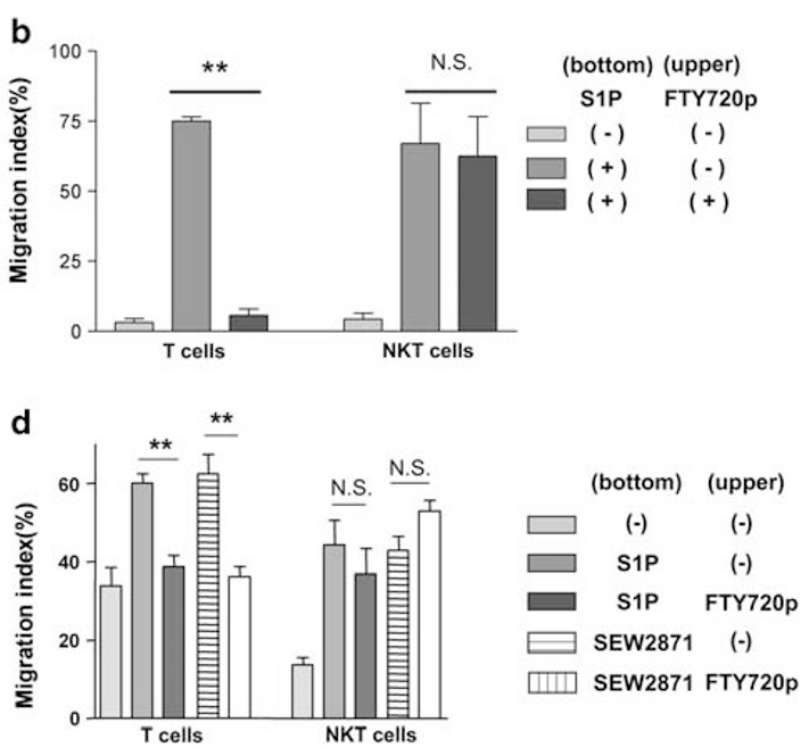

Figure 2 S1P induces the migration of T and NKT cells through S1P ${ }_{1}$, whereas FTY720 inhibits the migration of T cells but not of NKT cells. (a) Mononuclear cells obtained from the livers of B6 mice were pre-incubated with FTY720p $(1 \mu \mathrm{g})$, or PTX (50 $\mathrm{ng})$, and then washed with PBS. These cells were incubated in the upper chamber of a transwell system, whereas $600-800 \mu$ l of media containing $1 \mu \mathrm{g} / \mathrm{ml}$ of S1P or SEW2871 was placed in the bottom chamber. After $12 \mathrm{~h}$, the cells from the bottom chamber were removed and stained with anti-NK1.1 and TCR- $\beta$ mAbs. (b-d) Sorted NK1.1 $1^{+}$TCR- $\beta^{+}$NKT and NK1.1 $1^{-}$TCR- $\beta^{+}$ T cells were pre-incubated with or without FTY720p $(1 \mu \mathrm{g})$ for $30 \mathrm{~min}$ and then washed with PBS. These cells were incubated in the upper chamber of a transwell system, whereas S1P $(1 \mu \mathrm{g} / \mathrm{ml}$ ) was placed in the bottom chamber. After $24 \mathrm{~h}$ (panels b and c) or $12 \mathrm{~h}$ (panel d), the cells were taken from the upper and bottom chambers, and analyzed by flow cytometry after staining with anti-NK1.1 and TCR- $\beta$ mAbs (panels b and c), or without staining with these antibodies (panel d). (Panels $a, b$, and d) The percentage of migration of the T and NKT cells is shown. (Panels a-d) The results shown are representative of three independent experiments. (NS, not significant; ${ }^{*} P<0.05$ and ${ }^{* * P}<0.01$ ).

with $\alpha$-GalCer + S1P or FTY720 and measured the serum levels of IL-4, IFN- $\gamma$, IL-10, and IL-13. The administration of FTY720 or S1P to B6 mice injected with $\alpha$-GalCer reduced IL-4, IFN- $\gamma$, IL-10, and IL-13 production in the serum compared with B6 mice injected with $\alpha$-GalCer alone (Figure $3 b$ ). These findings indicate that FTY720 and S1P suppress cytokine production in NKT cells in the presence of TCR signals in vitro and in vivo. Next, we investigated whether the suppressive effects of FTY720 and S1P on NKT cells are mediated by S1P receptors, and which S1P receptor contributes the most to the inhibition of NKT cell cytokine production. NKT cells were pretreated with PTX, and then incubated with $\alpha$-GalCer + FTY720 or S1P. After incubation, the amount of IL- 4 and IFN- $\gamma$ in the culture supernatant was measured. PTX restored the production of IL-4 and IFN- $\gamma$ in NKT cells incubated with $\alpha$-GalCer + FTY720 or S1P (Figure 3c), indicating that FTY720 or S1P-mediated suppression of NKT cell cytokine production depends on $\mathrm{G}_{\mathrm{i} / \mathrm{o}}$ proteins coupled to S1P receptors. These findings suggest that FTY720 and S1P suppress cytokine production in NKT cells through $\mathrm{S}_{1} \mathrm{P}_{1}$.

T-bet and GATA-3 are key transcription factors that regulate the expression of Th1/Th2 cytokine genes, respectively. ${ }^{37-39}$ Therefore, it has been hypothesized that T-bet 

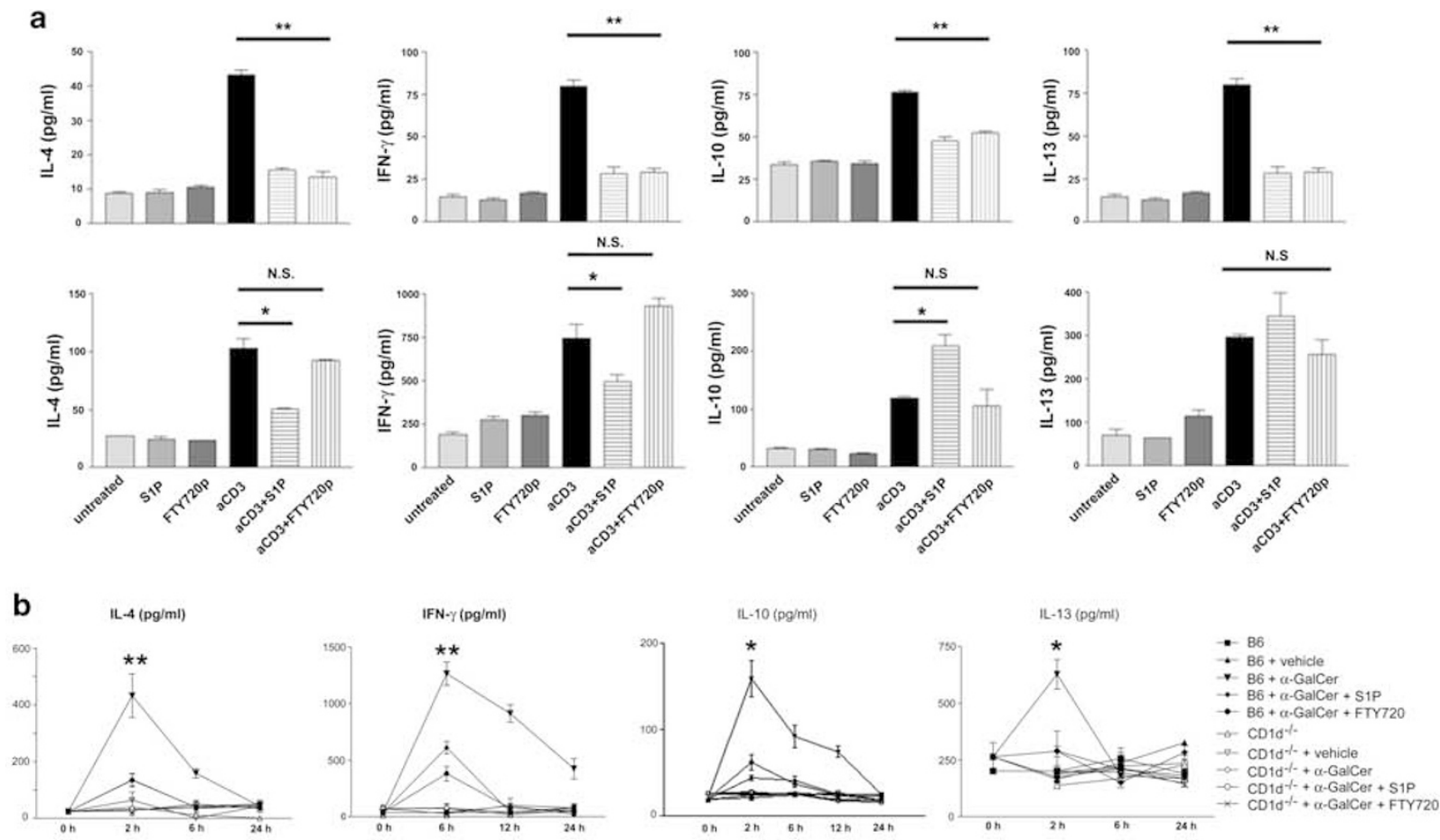

c
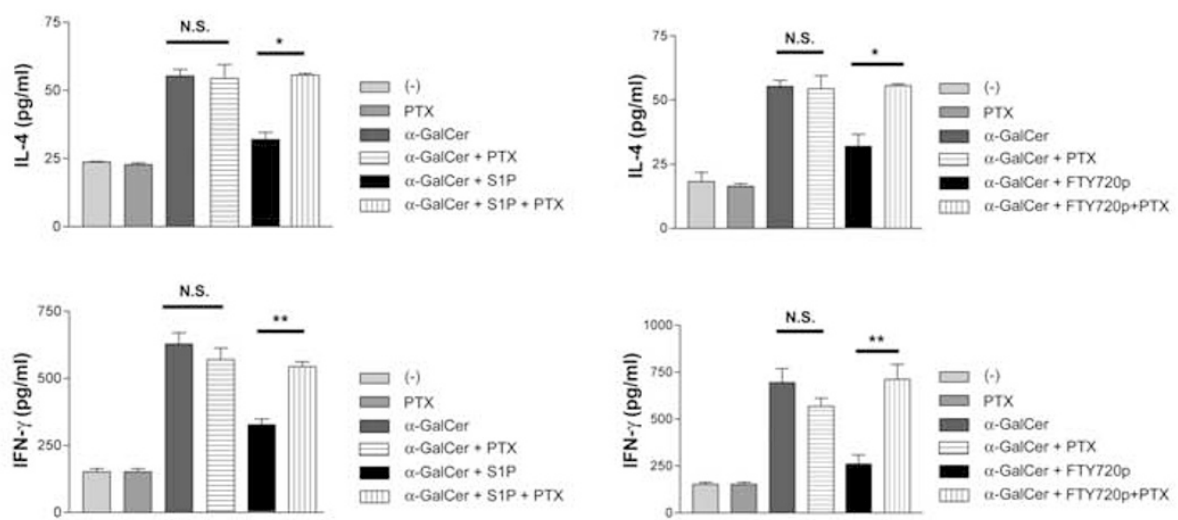

d

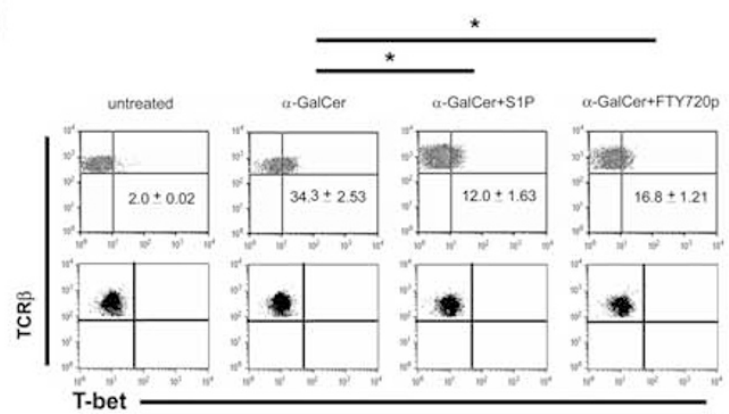

e

Spleen

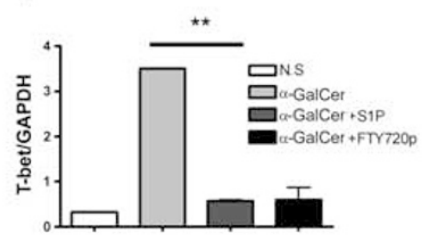

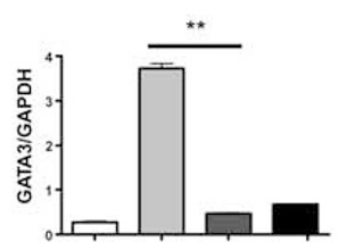

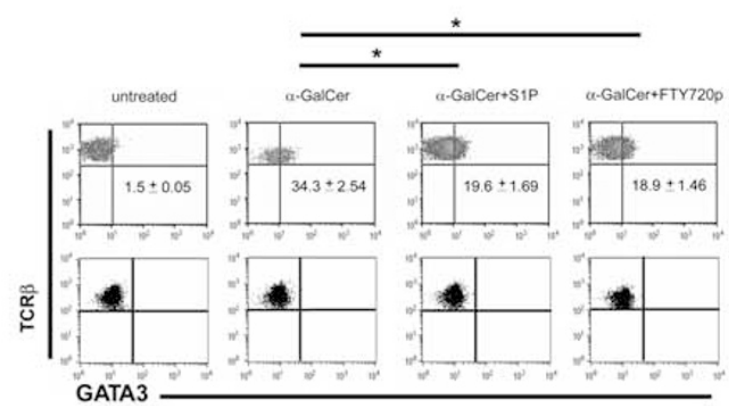

Liver
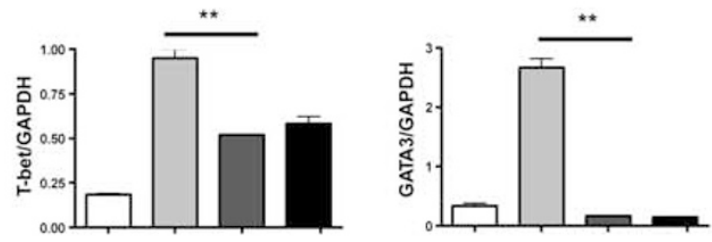
and/or GATA-3 might contribute to the reduction in cytokine production by NKT cells through S1P receptor engagement. Thus, we examined the intracellular expression of T-bet and GATA-3 in B6 mouse NKT cells stimulated with $\alpha$-GalCer + FTY720p or S1P. NKT cells stimulated with $\alpha$-GalCer alone showed an increase in both T-bet and GATA-3 expression, whereas $\alpha$-GalCer did not alter the expression of T-bet or GATA-3 in T cells (Figure 3d). However, FTY720por S1P-mediated S1P receptor engagement reduced the intracellular expression of T-bet and GATA-3 in NKT cells in the presence of TCR signaling compared with NKT cells stimulated with $\alpha$-GalCer alone (Figure $4 \mathrm{~d}$ ). Consistent with flow cytomeric analysis, real-time PCR analysis showed that FTY720p reduced the expression levels of T-bet and GATA-3 in splenocytes or liver mononuclear cells stimulated with $\alpha$-GalCer (Figure $3 \mathrm{~d}$ ). These findings suggest that FTY720p and S1P reduce the expression of T-bet and GATA-3, which in turn suppress cytokine production by NKT cells on TCR engagement. Moreover, T-bet and GATA-3 may be involved in suppressing cytokine production in FTY720- and S1Ptreated NKT cells.

\section{FTY720 Inhibits Antibody-Induced Arthritis by Suppressing NKT Cell Cytokine Production but not Migration}

NKT cells have an indispensable role in the development of antibody-induced joint inflammation by suppressing TGF- $\beta 1$ production in joint tissues, which in turn is dependent on IL-4 and IFN- $\gamma$ secreted from NKT cells. ${ }^{4}$ Therefore, we hypothesized that FTY720 suppresses cytokine production by NKT cells in joint tissues, which contributes to a reduction in joint inflammation. To investigate the specific effects of FTY720 on NKT cells, sorted NKT cells treated with or without FTY720p in vitro were administered to $\mathrm{CD} 1 \mathrm{~d}^{-1-}$ mice with antibody-induced joint inflammation. As previously reported, the $\mathrm{B} 6$ mice showed measurable joint swelling after serum transfer, whereas $\mathrm{CD}_{1} \mathrm{~d}^{-1-}$ mice were resistant to the development of arthritis. ${ }^{4}$ Joint swelling in $\mathrm{CD} \mathrm{d}^{-1-}$ mice given NKT cells pre-incubated with FTY720p was minimal, as in $\mathrm{CD}_{1} \mathrm{~d}^{-/-}$mice, whereas $\mathrm{CD}_{\mathrm{d}} \mathrm{d}^{-/-}$mice given untreated NKT cells showed as much joint inflammation as did B6 mice (Figure 4a and b). IL-4 and IFN- $\gamma$ levels in the joint tissues of $\mathrm{CD}_{1 \mathrm{~d}}{ }^{-1-}$ mice given FTY720p-pretreated NKT cells by adoptive transfer were lower than those in $\mathrm{CD}_{1} \mathrm{~d}^{-1-}$ mice, given untreated NKT cells in a $\mathrm{K} / \mathrm{BxN}$ serum transfer model (Figure 4c). Moreover, the transcription of TGF- $\beta 1$ was increased in $\mathrm{CD} 1 \mathrm{~d}^{-1-}$ mice adoptively transferred with FTY720p-pretreated NKT cells $v s$ CD1d ${ }^{-1-}$ mice transferred with untreated NKT cells from B6 mice (Figure 4c). To investigate how many NKT cells had infiltrated the joint tissues, we measured the V $\alpha 14-\mathrm{J} \alpha 18$ TCR mRNA level in the joint tissues of B6, CD1d ${ }^{-/-}$, and CD1d ${ }^{-1-}$ mice given FTY720p-pretreated or untreated NKT cells in a $\mathrm{K} / \mathrm{BxN}$ serum transfer arthritis model. The transcription of $\mathrm{V} \alpha 14-\mathrm{J} \alpha 18$ TCR in the joint tissues of $\mathrm{CD}^{-1-} \mathrm{d}^{-1}$ mice given NKT cells with or without FTY720p-pretreatment was similar to that in the joint tissues of B6 mice, whereas no transcription was detected in the joint tissues of $\mathrm{CD}^{-1-}$ mice (Figure 4c). These data indicate that FTY720p does not inhibit the migration of NKT cells into the joints of mice with antibody-induced joint inflammation. Together, these data indicate that FTY720 specifically suppresses cytokine production in NKT cells but not their migration into the joints, which contributes to a reduction in antibody-induced joint inflammation. Next, to determine the therapeutic effects of FTY720 on antibody-induced arthritis through NKT cells, we examined joint inflammation in $\mathrm{B} 6$ or $\mathrm{CD} \mathrm{d}^{-1-}$ mice injected with FTY720 in a $\mathrm{K} / \mathrm{BxN}$ serum transfer arthritis model. FTY720 significantly decreased joint inflammation in the B6 mice, whereas joint inflammation was markedly decreased in CD1d ${ }^{-1-}$ mice, and addition of FTY720 exerted a minimal effect (Figure 5a). On K/BxN serum transfer, lesser IL-4 and IFN- $\gamma$ was present in the joint tissues of FTY720treated B6 mice than in control B6 mice. Conversely, the FTY720-treated B6 mice had a greater amount of TGF- $\beta 1$, as did the $\mathrm{CD} 1 \mathrm{~d}^{-1-}$ mice, whereas no alteration in cytokine level was observed in the FTY720-treated or control CD1d ${ }^{-1-}$ mice (Figure 5b). Real-time PCR showed that V $\alpha 14-\mathrm{J} \alpha 18$

Figure 3 S1P and FTY720 suppress NKT cell cytokine production through S1P ${ }_{1}$. (a) Sorted NK1.1 ${ }^{+}$TCR- $\beta^{+}$NKT cells $\left(2 \times 10^{5}\right.$ per well) (upper panel) were incubated with S1P $(1 \mu \mathrm{g} / \mathrm{ml})$ or FTY720p $(1 \mu \mathrm{g} / \mathrm{ml})$ in the presence or absence of anti-CD3 mAb $(0.5 \mu \mathrm{g} / \mathrm{ml})$ for $48 \mathrm{~h}$ in 12 -well plates and CD4 ${ }^{+} \mathrm{T}_{\text {cells }}$ $\left(1 \times 10^{6}\right.$ per well) (lower panel) were incubated in the presence or absence of anti-CD3 mAb( $\left.1 \mu \mathrm{g} / \mathrm{ml}\right)+$ anti-CD28( $\left.1 \mu \mathrm{g} / \mathrm{ml}\right) \mathrm{mAbs}$. The amount of IL-4, IFN- $\gamma$, IL-10, or IL-13 in the culture supernatant was measured by ELISA. (NS, not significant, ${ }^{\star} P<0.05$ and ${ }^{* * P}<0.01$, anti-CD3 vs anti-CD3 + S1P or antiCD3 + FTY720p, anti-CD3 + anti-CD28 mAbs vs anti-CD3 + anti-CD28 mAbs + S1P or anti-CD3 + anti-CD28 mAbs + FTY720p). (b) B6 and CD1d ${ }^{-1-}$ mice were

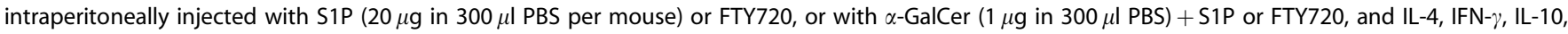
and IL-13 were measured at various time points by ELISA. The data shown are the means \pm s.d. for three mice in each group. Similar results were obtained from three independent experiments. $\left({ }^{*} P<0.05\right.$ and ${ }^{*} P$ P $<0.01$, B6 mice $+\alpha$-GalCer vs B6 mice $+\alpha$-GalCer + S1P or B6 mice $+\alpha$-GalCer + FTY720). (c) Liver mononuclear cells from the B6 mice were incubated with $\alpha$-GalCer $(220 \mathrm{ng})$, S1P $(1 \mu \mathrm{g})$, PTX (50 ng), or FTY720p (1 $\mu$ g), or with PTX, PTX + S1P, or FTY720p in the presence of $\alpha$-GalCer. The production of IL- 4 or IFN- $\gamma$ was then measured in the culture supernatant by ELISA. The results shown are representative of four independent experiments $\left({ }^{*}>0.05\right.$ and $\left.{ }^{* * P}<0.01\right)$. (d) Liver mononuclear cells from the B6 mice were incubated with $\alpha$-GalCer $(220 \mathrm{ng} / \mathrm{ml})$ or with $\alpha$ GalCer + S1P or FTY720p for $24 \mathrm{~h}$, and the intracellular expression of T-bet and GATA-3 in gated NK1.1 $1^{+}$TCR- $\beta^{+}$NKT or NK1.1 $1^{-}$TCR- $\beta^{+}$T cells was evaluated. $\left({ }^{*} P<0.05\right.$ and ${ }^{*} P<0.01 \alpha$-GalCer vs $\alpha$-GalCer + S1P or $\alpha$-GalCer + FTY720). (e) The expression levels of T-bet and GATA-3 was estimated in B6 mouse splenocytes and liver mononuclear cells incubated with S1P $(1 \mu \mathrm{g} / \mathrm{ml})$ or FTY720p $(1 \mu \mathrm{g} / \mathrm{ml})$ in the presence of $\alpha$-GalCer (200 ng/ml) for $24 \mathrm{~h}$ using real-time PCR. ${ }^{* * P}<0.01 \alpha$-GalCer vs $\alpha$-GalCer + S1P or $\alpha$-GalCer + FTY720). (Panels a-e) The data shown are the means $\pm s$.d. for three mice in each group, and representative of three independent experiments. 

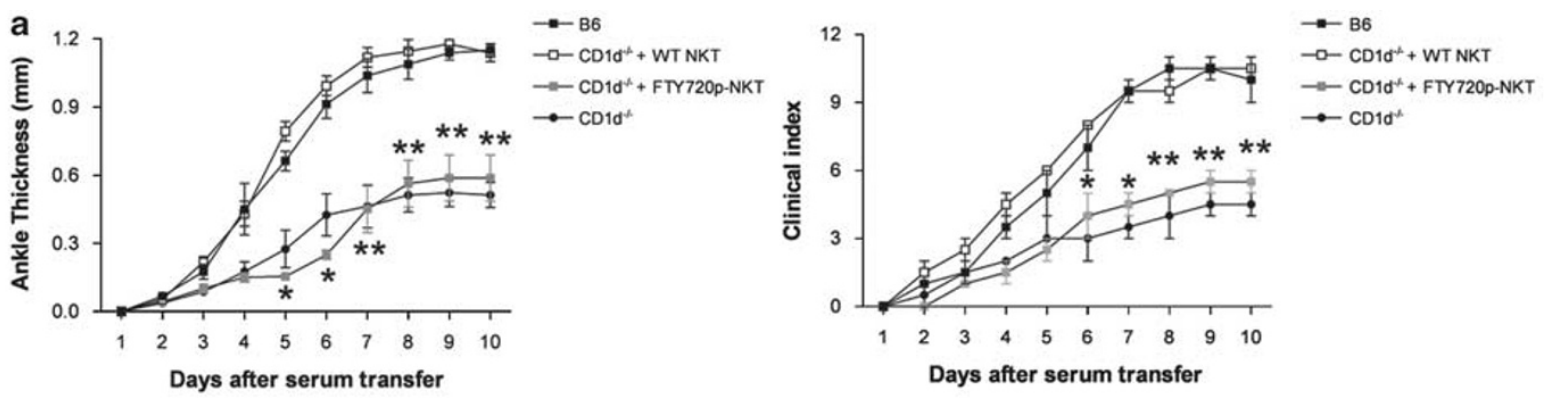

b B6 $\mathrm{CD} 1 \mathrm{~d}^{-1-}$
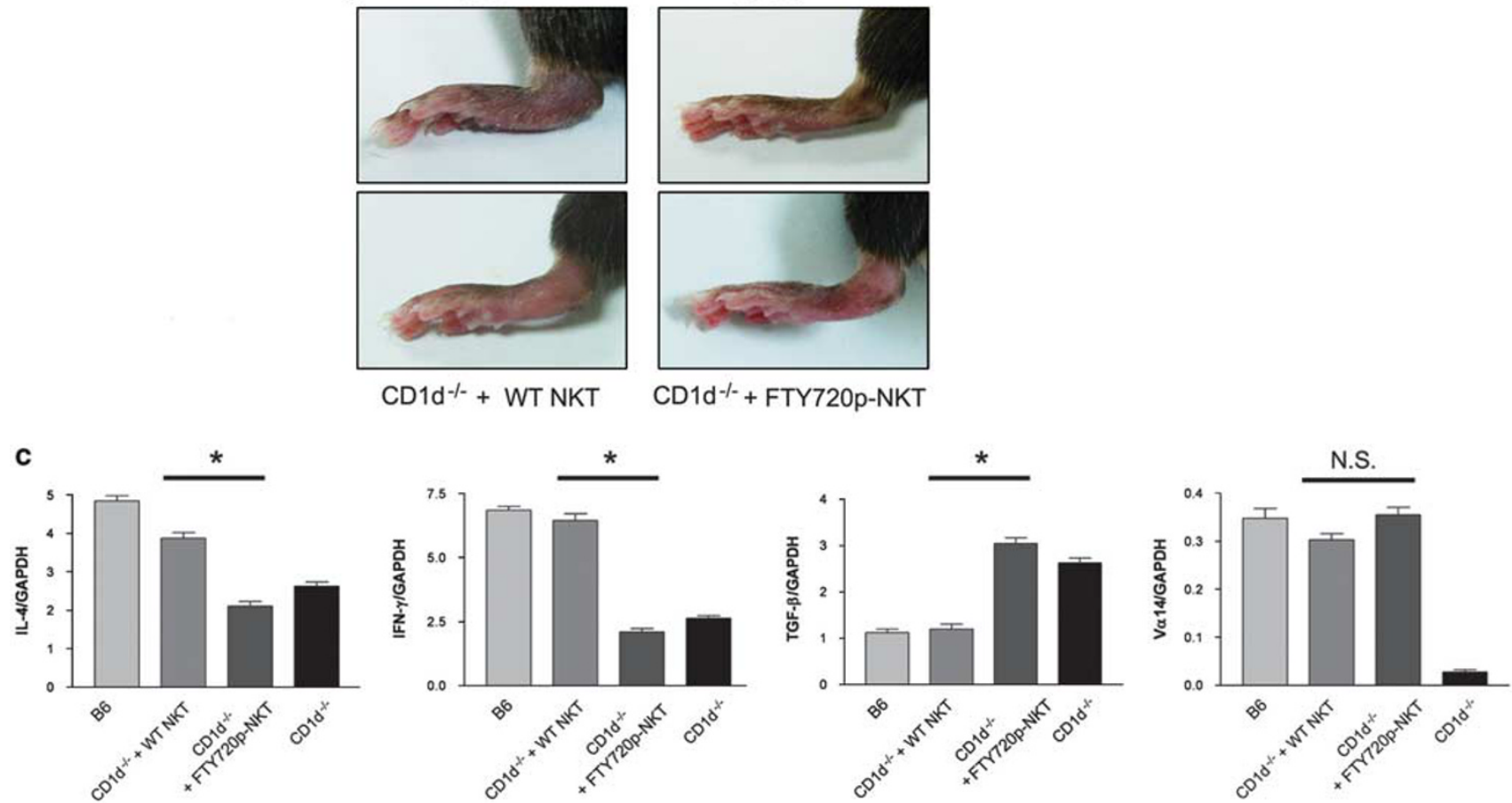

Figure 4 FTY720 inhibits antibody-induced arthritis by suppressing NKT cell cytokine production but not migration. (a-c) NKT cells were sorted from freshly isolated B6 liver mononuclear cells according to NK1.1 and TCR- $\beta$ expression. Sorted NKT cells $\left(3 \times 10^{5}\right.$ cells mouse $\left.{ }^{-1}\right)$ pre-incubated with (FTY720p-NKT) or without FTY720p (WT NKT), and then washed twice with PBS, which were administered to CD1 $\mathrm{d}^{-/-}$mice before the transfer of K/BxN serum. In B6, CD1d $\mathrm{d}^{-/-}$, and $\mathrm{CD} 1 \mathrm{~d}^{-/-}$mice given sorted NKT cells pretreated with or without FTY720p, antibody-induced joint inflammation was induced by injecting K/BxN serum. (Panel a) Ankle thickness in the mice and their clinical scores $\left({ }^{*} P<0.05\right.$ and ${ }^{*} P<0.01, \mathrm{CD}^{*} \mathrm{~d}^{-1-}$ mice + WT NKT vs CD1d ${ }^{-1-}$ mice + FTY720p-NKT). (Panel b) Images of the ankles of $\mathrm{B} 6, \mathrm{CD} 1 \mathrm{~d}^{-/-}$, and CD1d ${ }^{-1-}$ mice given sorted NKT cells pretreated with or without FTY720p. (Panel c) IL-4, IFN- $\gamma$, TGF- $\beta 1$, and V $\alpha 14-$

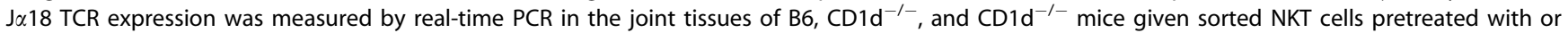
without FTY720p 10 days after K/BxN serum transfer. $\left({ }^{*} P<0.05\right.$ and ${ }^{* *} P<0.01, \mathrm{CD}^{*} \mathrm{~d}^{-1-}$ mice + WT NKT vs CD1d ${ }^{-1-}$ mice + FTY720p-NKT). (Panels a-c) The results shown are representative of three independent experiments. ( $n=3$ in each group).

TCR transcription in the joint tissues of FTY720-treated B6 mice was similar to that in the joint tissues of $\mathrm{B} 6$ control mice (Figure 5c). Thus, FTY720 is a strong therapeutic candidate for antibody-induced joint inflammation given its ability to suppress cytokine production in NKT cells without affecting their infiltration into joint tissues.

\section{DISCUSSION}

It was recently shown that NKT cells exhibit defects in egression from the thymus into the periphery in thymocytespecific $\mathrm{S}_{1} \mathrm{P}_{1}^{-1-}$ mice, suggesting that $\mathrm{S} 1 \mathrm{P}$ has critical roles in promoting NKT cell migration. ${ }^{26}$ Consistent with that suggestion, our study showed that S1P induces the migration of NKT cells in vitro. Moreover, S1P downregulated the production of IL-4, IFN- $\gamma$, IL-10, and IL-13 in NKT cells by $\mathrm{S}_{1} \mathrm{P}_{1}$ engagement. In a K/BxN serum transfer arthritis model, S1P attenuated antibody-induced joint inflammation by suppressing IL- 4 and IFN- $\gamma$ production in NKT cells (data not shown). These findings suggest that S1P has essential roles in the migration and cytokine production of NKT cells in vivo through the engagement of $\mathrm{S}_{1} \mathrm{P}_{1}$. In conventional $\mathrm{T}$ cells, S1P also regulates migration from the thymus and secondary lymphoid organs into the circulatory system, and cytokine production by the downregulation of IL-4 and 

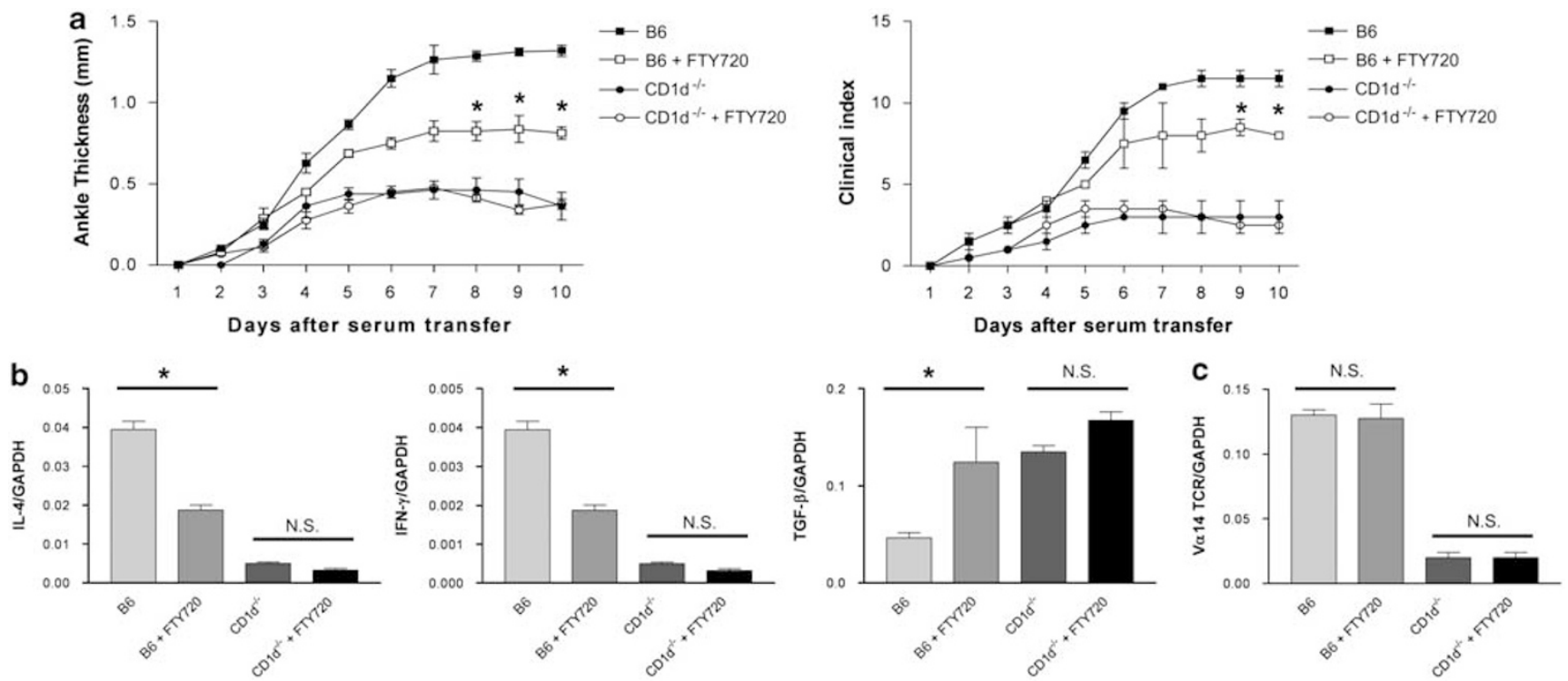

Figure 5 The administration of FTY720 suppresses antibody-induced joint inflammation in mice. (a-c) B6 and CD1d ${ }^{-1-}$ mice were injected with or without FTY720 in a K/BxN serum transfer model. (Panel a) Ankle thickness in mice and their clinical scores. $\left({ }^{*} P<0.05\right.$ and ${ }^{* * P}<0.01, \mathrm{~B} 6$ mice $v s$ B6 mice + FTY720). (Panel b) IL-4, IFN- $\gamma$, TGF- $\beta 1$ and (panel c) V $\alpha 14-J \alpha 18$ TCR expression was measured by real-time PCR in the joint tissues of FTY720-treated B6 and CD1d ${ }^{-/-}$ mice. $\left({ }^{*} P<0.05\right.$ and ${ }^{* * P}<0.01$, B6 mice vs B6 mice + FTY720, or CD1 $d^{-1-}$ mice vs CD1d ${ }^{-1-}$ mice + FTY720). (Panels a-c) The results shown are representative of five independent experiments ( $n=3$ in each group).

IFN- $\gamma$ and enhancement of IL-10 production as shown in Figure $3 \mathrm{a}^{21}$ whereas FTY720 does not alter cytokine production in T cells. ${ }^{18,25}$ Unlike NKT cells, two types of S1P receptors are differentially responsible for the regulation of migration and cytokine production in $\mathrm{T}$ cells: $\mathrm{S}_{1} \mathrm{P}_{1}$ enhances the migration of $\mathrm{T}$ cells, whereas $\mathrm{S} \mathrm{P}_{4}$ modulates cytokine production by $\mathrm{T}$ cells. ${ }^{21}$ In addition, $\mathrm{S} \mathrm{P}_{5}$ regulates NK cell trafficking in vivo. ${ }^{40}$ Thus, $\mathrm{S}_{1} \mathrm{P}_{1}$ provides the signals necessary for the S1P-mediated migration of T and NKT cells, whereas $\mathrm{S} \mathrm{P}_{5}$ regulates NK cell trafficking in vivo. As far as cytokine production is concerned, $\mathrm{S}_{1} \mathrm{P}_{1}$ regulates the $\mathrm{S} 1 \mathrm{P}$-mediated modulation of cytokine production by NKT cells, whereas this regulation is achieved by $\mathrm{S}_{4} \mathrm{P}_{4}$ in $\mathrm{T}$ cells.

FTY720, a homolog of S1P, induces lymphopenia in the blood by sequestering $\mathrm{T}$ cells in the lymph nodes, resulting in $\mathrm{S} 1 \mathrm{P} / \mathrm{S} 1 \mathrm{P}_{1}$-dependent immune suppression in vivo. ${ }^{23,41}$ Unlike $\mathrm{T}$ cells, NKT cells did not exhibit FTY720-induced sequestration in lymphoid organs. Moreover, FTY720p inhibited S1P-induced T-cell migration in vitro, but minimally suppressed NKT cell migration. However, it was consistently found in our experiments that FTY720 injection slightly increased T-cell number in the spleen, although FTY720 did not increase the number of $\mathrm{T}$ cells in the spleen in several reports. Recently, Kurashima et $a l^{42}$ showed that FTY720 inhibited the migration of pathogenic $\mathrm{CD} 4{ }^{+} \mathrm{T}$ cells from the spleen into the large intestine, resulting in an accumulation of these $\mathrm{T}$ cells in the spleen and preventing allergic diarrhea. Therefore, it should be further investigated for pharmacological effects of FTY720 on splenic T-cell migration.
In a K/BxN serum transfer arthritis model, FTY720 did not prevent NKT cells from infiltrating into the joint tissues of B6 mice. These data indicate that FTY720 minimally affects NKT cell migration and infiltration into target organs during the immune response in vivo, which is consistent with recently published results. ${ }^{26}$ Two possible mechanisms by which FTY720 sequesters $\mathrm{T}$ cells in secondary lymphoid organs have been suggested. ${ }^{35}$ First, the internalization of $\mathrm{S}_{1} \mathrm{P}_{1}$ after engagement by FTY720 may inhibit S1P gradient-dependent T-cell migration. Second, the FTY720-mediated engagement of $\mathrm{S}_{1} \mathrm{P}_{1}$ on endothelial cells may induce closure of the stromal gates proximal to the lymphatic sinus, resulting in the prevention of $\mathrm{T}$ cells from entering into the efferent lymphatic vessels. ${ }^{35}$ Alternatively, a recent study has suggested that the increased resistance of NKT cells to sequestration from the blood into the secondary lymphoid organs may be attributed to the low cell-surface expression of CD62L. ${ }^{26}$ Moreover, it was shown that FTY720-mediated homing of T cells was dependent on various chemokines (such as CCL19, CCL21, VLA- $4 \alpha$, and $\mathrm{CD} 44^{43}$ ), and chemokine receptors, such as CCR2, CCR5, CCR7, and CXCR4. ${ }^{44}$ These findings suggest that the differential modulation of chemokine production and chemokine receptor expression in T and NKT cells by FTY720 might partly explain the mechanisms by which FTY720 differentially affects the migration of these cells in secondary lymphoid organs. However, the mechanisms described above for the FTY720-mediated sequestration of T cells do not seem to be mutually exclusive. Combined, the differential kinetics of $\mathrm{S}_{1} \mathrm{P}_{1}$ internalization between NKT cells 
and $\mathrm{T}$ cells, the stromal gate-dependent, CD62L-, and chemokine/chemokine receptor-mediated mechanisms may be possible explanations for the resistance of NKT cells to FTY720-mediated sequestration.

In vitro assays showed that FTY720p does not alter the proliferation or cytokine production in $\mathrm{T}$ cells, but instead sequesters circulating $\mathrm{T}$ cells in lymphoid organs. ${ }^{41,45-49}$ Unlike T cells, FTY720p inhibited the TCR-mediated cytokine production of NKT cells through $\mathrm{S}_{1} \mathrm{P}_{1}$, whereas it did not regulate the S1P-induced migration of NKT cells in vitro. Furthermore, FTY720 attenuated antibody-induced joint inflammation by suppressing cytokine production in NKT cells, whereas FTY720 minimally inhibited NKT cell infiltration into joint tissues. On FTY720p treatment, the NKT cells altered their expression of transcription factors such as T-bet and GATA-3, whereas conventional T cells did not. These findings indicate that FTY720 regulates immune responses in vivo by suppressing cytokine production in NKT cells, and that different intrinsic factors may be involved in the cellular response to FTY720 in T and NKT cells. Recently, it was reported that FTY720 induces apoptosis in leukemic cells in acute lymphoblastic leukemia and chronic lymphocytic leukemia, and in T cells. ${ }^{50,51}$ These findings suggest that FTY720 also induces apoptosis in NKT cells, which may contribute to the reduction of cytokine production by NKT cells in vitro and in vivo. However, we found that FTY720 does not induce apoptosis in NKT cells (data not shown), indicating that the suppressive effect of FTY720 on cytokine production in NKT cells is not due to apoptosis. Moreover, PTX, a $G_{i / o}$ protein inhibitor, inhibited FTY720 or S1Pmediated suppression of cytokine production by NKT cells, which were stimulated with $\alpha$-GalCer in vitro. On the basis of these findings, it is clear that $\mathrm{S}_{1} \mathrm{P}_{1}$ engagement mediates the S1P- or FTY720p-induced suppression of cytokine production in NKT cells.

For therapeutic purposes, many groups have focused on the development of activating rather than suppressive reagents because NKT cells have protective roles in most autoimmune diseases, transplantation, and tumor surveillance. However, several studies have shown that NKT cells also promote the development or progression of immune diseases, such as asthma, ${ }^{14}$ rheumatoid arthritis, ${ }^{4}$ and atherosclerosis. ${ }^{15}$ Therefore, there is a need for therapeutic strategies to inhibit these immune diseases by inhibiting NKT cell function. Our study clearly shows that FTY720 inhibits cytokine production but not joint tissue migration of NKT cells in an antibody-induced arthritis model, suggesting that FTY720 may be a useful therapeutic agent for the suppression of NKT cell cytokine production. The arthritis in our experiments was completely suppressed by the adoptive transfer of sorted NKT cells pretreated with FTY720 in CD1d ${ }^{-1-}$ mice, and moreover, $\mathrm{K} / \mathrm{BxN}$ serum transfer-induced arthritis depends on innate immune system rather than on adaptive immune response. ${ }^{52}$ Therefore, it is less likely that the suppressive effect of FTY720 on joint inflammation was partly attributable to suppression of T-cell migration into the joint tissues in the $\mathrm{K} / \mathrm{BxN}$ serum transfer model. Similar to antibody-induced arthritis, NKT cells promote asthma and atherosclerosis by producing various cytokines. ${ }^{4,14,15}$ On the basis of these findings, the suppression of cytokine production by NKT cells may be a useful therapeutic strategy for preventing asthma and atherosclerosis, as shown for antibody-induced joint inflammation. ${ }^{14,15}$ Moreover, FTY720 attenuates asthma, arthritis, and atherosclerosis in animal models. ${ }^{53-55}$ Therefore, we hypothesize that the suppressive effects of FTY720 on asthma and atherosclerosis may partly be attributed to the inhibition of cytokine production by NKT cells. Taken together, these data indicate that FTY720 is a candidate NKT cell-based therapeutic agent for the regulation of immune diseases, such as rheumatoid arthritis, asthma, and atherosclerosis.

In conclusion, FTY720 suppresses cytokine production in NKT cells, whereas it minimally affects their migration, which is distinct from the FTY720-mediated sequestration of T cells. Thus, FTY720 may be a useful part of NKT cell-based immune therapies to treat immune diseases promoted by NKT cells.

\section{ACKNOWLEDGEMENTS}

We thank all members of the Department of Experimental Animals at the Clinical Research Institute of Seoul National University Hospital for animal management. This work was supported by the KBRDG Initiative Research Program (KBRDG, Korea) and the Program aims for the Development of Biotechnologies (F104AD010010-06A0401-01010 and F104AC010002-07A0301-00250).

\section{DISCLOSURE/CONFLICT OF INTEREST}

The authors declare no conflict of interest.

1. Taniguchi M, Harada $M$, Kojo $S$, et al. The regulatory role of $V \alpha 14$ NKT cells in innate and acquired immune response. Annu Rev Immunol 2003;21:483-513.

2. Lantz $\mathrm{O}$, Bendelac $\mathrm{A}$. An invariant T cell receptor alpha chain is used by a unique subset of major histocompatibility complex class I-specific $\mathrm{CD}^{+}$and $\mathrm{CD}^{-} 8^{-} \mathrm{T}$ cells in mice and humans. J Exp Med 1994;180:1097-1106.

3. Bendelac A. CD1: presenting unusual antigens to unusual $T$ lymphocytes. Science 1995;269:185-186.

4. Kim HY, Kim HJ, Min HS, et al. NKT cells promote antibody-induced joint inflammation by suppressing transforming growth factor $\beta 1$ production. J Exp Med 2005;201:41-47.

5. Kim HJ, Hwang SJ, Kim BK, et al. NKT cells play critical roles in the induction of oral tolerance by inducing regulatory $T$ cells producing $\mathrm{IL}-10$ and transforming growth factor beta, and by clonally deleting antigen-specific T cells. Immunology 2006;118:101-111.

6. Kim JH, Kim HY, Kim S, et al. Natural killer T (NKT) cells attenuate bleomycin-induced pulmonary fibrosis by producing interferongamma. Am J Pathol 2005;167:1231-1241.

7. Sharif S, Arreaza GA, Zucker P, et al. Activation of natural killer T cells by alpha-galactosylceramide treatment prevents the onset and recurrence of autoimmune Type 1 diabetes. Nat Med 2001;7: 1057-1062.

8. Seino KI, Fukao K, Muramoto $\mathrm{K}$, et al. Requirement for natural killer T (NKT) cells in the induction of allograft tolerance. Proc Natl Acad Sci USA 2001;98:2577-2581.

9. Kim JH, Choi EY, Chung DH. Donor bone marrow type II (non-V $\alpha 14 \mathrm{~J} \alpha 18$ CD1d-restricted) NKT cells suppress graft-versus-host disease by producing IFN- $\gamma$ and IL-4. J Immunol 2007;179:6579-6587. 
10. Hwang SJ, Kim S, Park WS, et al. IL-4-secreting NKT cells prevent hypersensitivity pneumonitis by suppressing IFN- $\gamma$-producing neutrophils. J Immunol 2006;177:5258-5268.

11. Cui J, Shin T, Kawano T, et al. Requirement for V $\alpha 14$ NKT cells in IL-12mediated rejection of tumors. Science 1997;278:1623-1626.

12. Gonzalez-Aseguinolaza G, Van Kaer L, Bergmann CC, et al. Natural killer $T$ cell ligand alpha-galactosylceramide enhances protective immunity induced by malaria vaccines. J Exp Med 2002;195:617-624.

13. Motohashi S, Ishikawa A, Ishikawa $E$, et al. A phase I study of in vitro expanded natural killer $T$ cells in patients with advanced and recurrent nonsmall cell lung cancer. Clin Cancer Res 2006;12(20 Pt 1):6079-6086.

14. Akbari O, Stock P, Meyer E, et al. Essential role of NKT cells producing IL-4 and IL-13 in the development of allergen-induced airway hyperreactivity. Nat Med 2003;9:582-588.

15. Tupin E, Nicoletti A, Elhage R, et al. CD1d-dependent activation of NKT cells aggravates atherosclerosis. J Exp Med 2004;199:417-422.

16. Yatomi $Y$, Yamamura S, Ruan F, et al. Sphingosine 1-phosphate induces platelet activation through an extracellular action and shares a platelet surface receptor with lysophosphatidic acid. J Biol Chem 1997;272: 5291-5297.

17. Hanel $P$, Andreani $P$, Graler MH. Erythrocytes store and release sphingosine 1-phosphate in blood. FASEB J 2007;21:1202-1209.

18. von Wenckstern $\mathrm{H}$, Zimmermann $\mathrm{K}$, Kleuser $\mathrm{B}$. The role of the lysophospholipid sphingosine 1-phosphate in immune cell biology. Arch Immunol Ther Exp (Warsz) 2006;54:239-251.

19. Schwab SR, Pereira JP, Matloubian M, et al. Lymphocyte sequestration through S1P lyase inhibition and disruption of S1P gradients. Science 2005;309:1735-1739.

20. Matloubian M, Lo CG, Cinamon G, et al. Lymphocyte egress from thymus and peripheral lymphoid organs is dependent on S1P receptor 1. Nature 2004;427:355-360.

21. Wang W, Graeler MH, Goetzl EJ. Type 4 sphingosine 1-phosphate $G$ protein-coupled receptor (S1P4) transduces S1P effects on T cell proliferation and cytokine secretion without signaling migration. FASEB J 2005;19:1731-1733.

22. Idzko M, Panther E, Corinti S, et al. Sphingosine 1-phosphate induces chemotaxis of immature and modulates cytokine-release in mature human dendritic cells for emergence of Th2 immune responses. FASEB J 2002;16:625-627.

23. Mandala S, Hajdu R, Bergstrom J, et al. Alteration of lymphocyte trafficking by sphingosine-1-phosphate receptor agonists. Science 2002;296:346-349.

24. Graler MH, Goetzl EJ. The immunosuppressant FTY720 down-regulates sphingosine 1-phosphate G-protein-coupled receptors. FASEB J 2004;18:551-553.

25. Xie JH, Nomura N, Koprak SL, et al. Sphingosine-1-phosphate receptor agonism impairs the efficiency of the local immune response by altering trafficking of naive and antigen-activated $\mathrm{CD} 4^{+} \mathrm{T}$ cells. J Immunol 2003;170:3662-3670.

26. Allende $\mathrm{ML}$, Zhou $\mathrm{D}$, Kalkofen DN, et al. S1P1 receptor expression regulates emergence of NKT cells in peripheral tissues. FASEB $J$ 2008;22:307-315.

27. Kim S, Lee $H$, Lee $M$, et al. Efficient synthesis of the immunosuppressive antigen FTY720. Synthesis 2006;2006:752-755.

28. Albert R, Hinterding K, Brinkmann V, et al. Novel immunomodulator FTY720 is phosphorylated in rats and humans to form a single stereoisomer. Identification, chemical proof, and biological characterization of the biologically active species and its enantiomer J Med Chem 2005:48:5373-5377.

29. Kim SLS, Lee T, Jung $S$, et al. Practical synthesis of KRN7000 form phytosphingosine. Synthesis 2004;22:847-850.

30. West Jr RE, Moss J, Vaughan M, et al. Pertussis toxin-catalyzed ADP-ribosylation of transducin. Cysteine 347 is the ADP-ribose acceptor site. J Biol Chem 1985;260:14428-14430.

31. Windh RT, Lee MJ, Hla T, et al. Differential coupling of the sphingosine 1-phosphate receptors Edg-1, Edg-3, and H218/Edg-5 to the G(i), G(q), and $\mathrm{G}(12)$ families of heterotrimeric $\mathrm{G}$ proteins. J Biol Chem 1999:274:27351-27358

32. Van Brocklyn JR, Graler MH, Bernhardt G, et al. Sphingosine-1-phosphate is a ligand for the $G$ protein-coupled receptor EDG-6. Blood 2000;95:2624-2629.

33. Malek RL, Toman RE, Edsall LC, et al. Nrg-1 belongs to the endothelial differentiation gene family of $\mathrm{G}$ protein-coupled sphingosine-1phosphate receptors. J Biol Chem 2001;276:5692-5699.
34. Jo E, Sanna MG, Gonzalez-Cabrera PJ, et al. S1P1-selective in vivoactive agonists from high-throughput screening: off-the-shelf chemical probes of receptor interactions, signaling, and fate. Chem Biol 2005; 12:703-715.

35. Yopp AC, Ledgerwood LG, Ochando JC, et al. Sphingosine 1phosphate receptor modulators: a new class of immunosuppressants. Clin Transplant 2006;20:788-795.

36. Chen $\mathrm{H}$, Paul WE. Cultured NK1.1 $1^{+} \mathrm{CD} 4^{+} \mathrm{T}$ cells produce large amounts of IL- 4 and IFN- $\gamma$ upon activation by anti-CD3 or CD1. J Immunol 1997:159:2240-2249.

37. Zhang DH, Cohn L, Ray $P$, et al. Transcription factor GATA-3 is differentially expressed in murine Th1 and Th2 cells and controls Th2specific expression of the interleukin-5 gene. J Biol Chem 1997:272:21597-21603.

38. Zheng W, Flavell RA. The transcription factor GATA-3 is necessary and sufficient for Th2 cytokine gene expression in CD4 T cells. Cell 1997;89:587-596.

39. Szabo SJ, Kim ST, Costa GL, et al. A novel transcription factor, T-bet directs Th1 lineage commitment. Cell 2000;100:655-669.

40. Walzer T, Chiossone L, Chaix J, et al. Natural killer cell trafficking in vivo requires a dedicated sphingosine 1-phosphate receptor. Nat Immunol 2007;8:1337-1344.

41. Chiba K. FTY720, a new class of immunomodulator, inhibits lymphocyte egress from secondary lymphoid tissues and thymus by agonistic activity at sphingosine 1-phosphate receptors. Pharmacol Ther 2005;108:308-319.

42. Kurashima $Y$, Kunisawa J, Higuchi $M$, et al. Sphingosine 1-phosphatemediated trafficking of pathogenic Th2 and mast cells for the control of food allergy. J Immunol 2007;179:1577-1585.

43. Honig SM, Fu S, Mao X, et al. FTY720 stimulates multidrug transporterand cysteinyl leukotriene-dependent $T$ cell chemotaxis to lymph nodes. J Clin Invest 2003;111:627-637.

44. Yopp AC, Fu S, Honig SM, et al. FTY720-enhanced T cell homing is dependent on CCR2, CCR5, CCR7, and CXCR4: evidence for distinct chemokine compartments. J Immunol 2004;173:855-865.

45. Brinkmann V, Chen S, Feng L, et al. FTY720 alters lymphocyte homing and protects allografts without inducing general immunosuppression. Transplant Proc 2001;33:530-531.

46. Chiba K, Yanagawa Y, Masubuchi Y, et al. FTY720, a novel immunosuppressant, induces sequestration of circulating mature lymphocytes by acceleration of lymphocyte homing in rats. I. FTY720 selectively decreases the number of circulating mature lymphocytes by acceleration of lymphocyte homing. J Immunol 1998;160: 5037-5044.

47. Yanagawa $\mathrm{Y}$, Hoshino $\mathrm{Y}$, Kataoka $\mathrm{H}$, et al. FTY720, a novel immunosuppressant, prolongs rat skin allograft survival by decreasing T-cell infiltration into grafts. Transplant Proc 1999;31:1227-1229.

48. Brinkmann V, Pinschewer D, Chiba K, et al. FTY720: a novel transplantation drug that modulates lymphocyte traffic rather than activation. Trends Pharmacol Sci 2000;21:49-52.

49. Yanagawa $Y$, Sugahara K, Kataoka H, et al. FTY720, a novel immunosuppressant, induces sequestration of circulating mature lymphocytes by acceleration of lymphocyte homing in rats. II. FTY720 prolongs skin allograft survival by decreasing $\mathrm{T}$ cell infiltration into grafts but not cytokine production in vivo. J Immunol 1998;160: 5493-5499.

50. Liu Q, Zhao X, Frissora F, et al. FTY720 demonstrates promising preclinical activity for chronic lymphocytic leukemia and lymphoblastic leukemia/lymphoma. Blood 2008;111:275-284.

51. Nagahara $Y$, Enosawa $S$, Ikekita M, et al. Evidence that FTY720 induces T cell apoptosis in vivo. Immunopharmacology 2000;48:75-85.

52. Ji H, Ohmura K, Mahmood U, et al. Arthritis critically dependent on innate immune system players. Immunity 2002;16:157-168.

53. Idzko $M$, Hammad $H$, van Nimwegen $M$, et al. Local application of FTY720 to the lung abrogates experimental asthma by altering dendritic cell function. J Clin Invest 2006;116:2935-2944.

54. Matsuura M, Imayoshi T, Okumoto T. Effect of FTY720, a novel immunosuppressant, on adjuvant- and collagen-induced arthritis in rats. Int J Immunopharmacol 2000;22:323-331.

55. Nofer JR, Bot M, Brodde M, et al. FTY720, a synthetic sphingosine 1 phosphate analogue, inhibits development of atherosclerosis in low-density lipoprotein receptor-deficient mice. Circulation 2007;115:501-508. 